\title{
DETERMINATION OF SIBUTRAMINE ADULTERATED IN HERBAL SLIMMING PRODUCTS USING TLC DENSITOMETRIC METHOD
}

Faculty of Pharmacy, Universitas Indonesia, Depok, West Java, Indonesia 16415.

Submitted: $09-12-2015$

Revised: $14-01-2016$

Accepted: 13-02-2016

*Corresponding author Hayun

Email:

hayun.ms06@gmail.com

\author{
Hayun*, Baitha P. Maggadani, Nurul Amalina
}

\begin{abstract}
Determination of sibutramine adulterated in herbal slimming product using thin layer chromatography (TLC) densitometric method with TLC silica gel $60 \mathrm{~F}_{254}$ aluminium plate as stationary phase and mixture of toluen-diethylamine (10:0.3) as mobile phase has been developed. The calibration curve in the concentration range of 0.50 to $5.00 \mu \mathrm{g} / \mathrm{spot}$ showed good linier relationship $\left(r^{2}=0.9986\right)$. The limit of detection and quantitation (LOD and LOQ) were 217.5ng and 724.9ng/spot, respectively. The method gave satisfactory specificity, linierity, precision and accuracy validation criteria and was applied for determination of sibutramine in herbal slimming products obtained from several drugstrores in Depok City, West Java, Indonesia. Results of the determination showed that six of seven samples analyzed were detected containing sibutramine $\mathrm{HCl}$ with the concentration of $2.45-26.24 \mathrm{mg}$ in a single dosage of slimming herbal products.
\end{abstract}

Key words: Sibutramine $\mathrm{HCl}$; Herbal Slimming Products; TLC, Densitometry; Validation Method.

\section{INTRODUCTION}

Herbal medicines play an important role as an alternative of synthetic drugs to improve people health in developing countries and increasingly popular in developed countries. This is mainly because of the general perceptions that they are safer than synthetic chemical drugs. Herbal medicines are traditional medicines containing active ingredients of plants, or other plant materials, or combinations thereof. But it is a fact that there are many herbal medicines adulterated with synthetic chemical drugs to enhance their efficacy of respective products in the claimed indications. The adulterations can cause a significant public health risks, especially after cosuming them in the long term (Haneef, 2013; Monika, 2011).

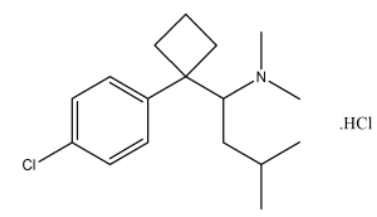

Figure1. Chemical structure of sibutramine $\mathrm{HCl}$

The adulteration practice violates the laws of many countries, but the presence of undeclare synthetic chemical drugs in the herbal products are still often found, including in the herbal slimming products (Departemen Kesehatan RI, 1994; WHO, 2005; Carvalho et al., 2011; BPOM RI, 2014; Khazan et al., 2014). The most common synthetic chemical drugs adulterated in herbal slimming product is sibutramine (Figure 1) (Phattanawasin, 2012; HAAD, 2012). This drug is a serotonine and noradrenaline reuptake inhibitors, causing an increase in the synaptic concentrations of these neurotransmitters, which then leads to the subsequent activation of $\alpha$-adrenoceptors, $\beta$ adrenoceptors and serotonin receptor $2 \mathrm{~A}$ and $2 \mathrm{C}$ subtypes $(5-\mathrm{HT} 2 \mathrm{~A} / 2 \mathrm{C})$. These interactions produce an eventual increase in satiety and energy expenditure, with a subsequent decreased body weight. However, since the year of 2010, sibutramine was withdrawn from the global market because of its unacceptable risk/benefit ratio. Sibutramine proved to have harmful side effects such as psychosis, hepatitis, arrhythmias and other cardiovascular diseases (Canadian, 2002; Oberholtzer, 2014). Those taking herbal slimming products containing undeclared sibutramine may be suffered from the above side effects ranging from headache to serious cardiovascular diseases, depending on the amount of drug consumed (Daglioglu and Akcan, 2012; Phattanawasin et al., 2012; 
Chen et al., 2010). In order to protect comsumer risks, screening and determination of sibutramine in the herbal slimming products available in the market is very important. For this purpose, several chromatographic methods have been reported, such as HPLC (Kanan et al., 2009; Ancuceanu et al., 2013; Khazan et al., 2014), LC-MS/MS (Boguzs et al., 2006; Aliburnu et al, 2012) and TLC/HPTLCdensitometry (Phattanawasin et al., 2012; Mathon et al., 2014; Aliburnu et al, 2012). TLC allows for greater flexibility in choice of chromatographic system (Adamovics, 1997). The method is simpler, more rapid and lower cost rather than HPLC and LC-MS/MS.

The purpose of this research reported here was to develop a new, alternative, simpler, lower operating cost and validated TLCdensitometric method for screening and determination of sibutramine in herbal slimming products available in the market, which was useful to small laboratories or local health authorities.

\section{MATERIAL AND METHODS Chemicals}

Sibutramine $\mathrm{HCl}$ RS (IPRS), methanol (Merck), toluene (Merck), n-hexane (Mallinckrodt), diethylamine (Merck), dragendorff reagent and 7 (seven) samples of various brands of herbal slimming products (AR, SU, LN, PL, $\mathrm{SL}, \mathrm{LK}, \mathrm{LM}$ ). All reagents and chemicals were analytical grade.

\section{Standar solution}

A working standard solution with concentration of $0.5 \mathrm{mg}$ sibutramine $\mathrm{HCl}$ per $\mathrm{mL}$ was obtained by diluting $1.0 \mathrm{~mL}$ stock solution $(5.0 \mathrm{mg}$ sibutramine $\mathrm{HCl}$ per $\mathrm{mL}$ ) with methanol to $10.0 \mathrm{~mL}$.

\section{Sample solution}

Sample solution was prepared as follows: a half of single dosage of homogenous sample was accurately weighed, placed in flask, added $5 \mathrm{~mL}$ methanol, stirried and sonicated for $15 \mathrm{~min}$, followed by addition of methanol to the volume of $10.0 \mathrm{~mL}$ and standing for $1 \mathrm{~h}$ so as insoluble part precipitate. The soluble part of the sample was used as sampel solution.

\section{Instrumentation and analytical conditions}

TLC analysis was performed on aluminium TLC plates coated with silica gel $60 \mathrm{~F}_{254}$ with $250 \mu \mathrm{m}$ thicknes (E.Merck, Darmstandt, Germany). TLC plate was cut to the size of $10 \mathrm{~cm} \times 3-8 \mathrm{~cm}$ depend on the number of samples/standard solution to be analyzed. Samples/standard solution were applied to the plate as spot using Nanomat completed with $2 \mathrm{uL}$ capilary tube (Camag, Swiszerland). The distance between each spot was $1.0 \mathrm{~cm}$. The plates was developed to a distance of about $7 \mathrm{~cm}$ using a mixture of toluen-diethylamine $(10: 0.3 \mathrm{v} / \mathrm{v})$ as mobile phase in a twin-through glass chamber which had been pre-saturated with mobile phase vapours. Densitometric scanning was performed at $227 \mathrm{~nm}$ with $\operatorname{Camag}^{\circledR}$ TLC Scanner III in reflectance-absorbance mode and operated by CATS software. The slit dimensions were $8 \mathrm{~mm} \times 0.4 \mathrm{~mm}$ and the scanning speed was $10 \mathrm{~mm} \mathrm{~s}^{-1}$.

\section{Method validation}

Validation of the analytical method was performed according to ICH Q2 guidelines (2005), including specificity, linearity, limit of detection (LOD), limit of quantitation (LOQ), precision and accuracy:

\section{Specificity}

The specificity of the TLC method was determined by comparing TLC densitometric chromatogram of blank sample (sample identified free of sibutramine), sibutramine $\mathrm{HCl}$ standard and sample addition (blank sample added sibutramine $\mathrm{HCl}$ standard). The method meets the specific criteria when the chromatogram peak of the sibutramine spot from sample addition was not interferenced by other components of the sample.

\section{Linearity}

The linearity was evaluated by determining the correlation coefficient $\left(\mathrm{r}^{2}\right)$ of linear regression analysis $(\mathrm{y}=\mathrm{bx}+\mathrm{a})$ of calibration curve contructed between peak area and drug concentration in the range of $0.50-5: 00 \mu \mathrm{g} /$ spot.

\section{Detection and quantitation limit}

LOD and LOQ determined using data of standard deviation of the response and the 


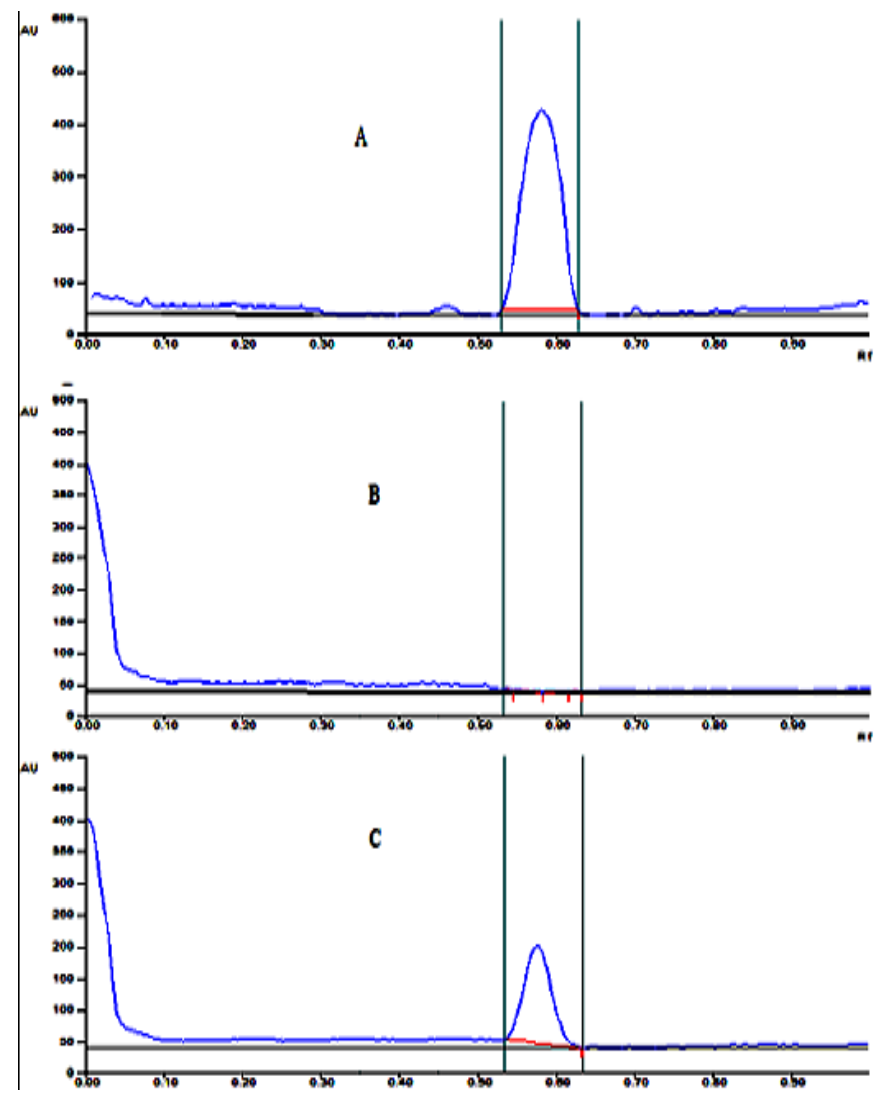

Figure 2. TLC densitometric chromatogram for specificity test. (A) Sibutramine $\mathrm{HCl}$ standard, (B) blank sample (free of sibutramine $\mathrm{HCl}$ ), and (C) sample spiked with sibutramine $\mathrm{HCl}$.

slope of the calibration curve. LOD and LOQ calculated using the equation of $3.3 \sigma / \mathrm{S}$ and 10 $\sigma / \mathrm{S}$, respectively. $\sigma$ is the standard deviation of the $y$-intercept of the regression line. $S$ is the slope of the calibration curve. The LOD and LOQ were confirmed by analyzing the spot of sibutramine $\mathrm{HCl}$ with the LOD and LOQ concentration. The detection limit is expressed in $\mathrm{ng} / \mathrm{spot}$.

Precision

The precision was performed by repeatability and intermediate presicion. Repeatability (intraday precision) was evaluated by determining the amount of standard sibutamine $\mathrm{HCl}$ at three different concentration levels (1, 2 and $3 \mu \mathrm{g} / \mathrm{spot})$ in triplicate. Intermediate precision was evaluated by repeating the determination in triplicate on two consecutive days. The relative standard deviation (RSD) values for repeatability and intermediate precision were calculated.

\section{Accuracy}

The accuracy was determined by adding known amount of standard sibutramine $\mathrm{HCl}$ to blank sample (sample identified free of the sibutramine $\mathrm{HCl}$ ) to give concentrations of 1,2 and $3 \mu \mathrm{g} / \mathrm{spot}$ and was analyzed by the proposed methods. The experiment was conducted in triplicate. A mean percent recovery was calculated.

\section{Analysis of sibutramine in herbal slimming product}

The sample solution and standard solution was spotted on the same plate, eluted and analyzed by the proposed methods. Identification of sibutramine in the samples was performed by comparing the similarity of Rf, UV spectrum and colour (after spraying with Dragendorff reagent) of the spot from sample with those from a standard. The amount of sibutramine $\mathrm{HCl}$ was calculated from peak area of the spot obtained before 
Tabel I. Intraday and intermediate precision study

\begin{tabular}{ccc}
\hline $\begin{array}{c}\text { Sibutramine } \mathbf{H C l} \\
\text { concentration }(\boldsymbol{\mu g} / \text { spot })\end{array}$ & Intraday precision $\left.{ }^{*}\right)$ & Intermediate precision ${ }^{*}$ \\
\hline 1 & 1.47 & 1.65 \\
2 & 1.43 & 1.54 \\
3 & 1.03 & 1.26 \\
\hline
\end{tabular}

Relative standard deviation (\% RSD, $\mathrm{n}=3$ )

Tabel II. Recovery Study (Accuracy)

\begin{tabular}{ccc}
\hline Sibutramine $\mathbf{H C l}$ added $(\boldsymbol{\mu g} / \mathbf{s p o t})$ & Recovery $\mathbf{( \% )}$ & Average recovery $(\mathbf{\%})$ \\
\hline 1 & $99.57 \pm 1.46$ & \\
2 & $100.32 \pm 1.43$ & $99.70 \pm 1,22$ \\
3 & $99.20 \pm 1.02$ & \\
\hline
\end{tabular}

Tabel III. The content of sibutramine $\mathrm{HCl}$ in herbal slimming products

\begin{tabular}{ccc}
\hline Sample Code & Dosage form & Amount \pm SD (mg/single dosage) \\
\hline AR & Capsule & $9.83 \pm 0.03$ \\
SU & Capsule & $2.45 \pm 0.01$ \\
DI & Capsule & $26.24 \pm 0.01$ \\
PL & Pil & ND* \\
SL & Capsule & $20.47 \pm 0.19$ \\
LK & Capsule & $15.97 \pm 0.11$ \\
LM & Capsule & $3.43 \pm 0.01$ \\
\hline
\end{tabular}

*) $\mathrm{ND}=$ not detected

spraying with Dragendorff reagent. Each sample was analyzed in triplicate. The results obtained were expressed as mean of sibutramine $\mathrm{HCl}$ content ( $\mathrm{mg}$ per one single dose).

\section{RESULTS AND DISCUSSION}

Sibutramine is the most commonly added illegally into herbal slimming products. Several papers have reported the application of TLC and HPTLCdensitometric method for the screening and determination of sibutramine adulterated in herbal slimming products. However, the method need to be further developed to obtain simpler and lower operating cost method.

In our study, the chromatographic system used was aluminum TLC plates coated with silica gel 60 F254 as stationary phase and mixture of two solvens as mobile phase. The chormatographic system was simpler and lower cost than that reported earlier. A mixture of toluene-diethylamine $(10: 0.3 \mathrm{v} / \mathrm{v})$ resulted a fairly compact spot with $\operatorname{Rf}$ of $0.58 \pm 0.02$ and short elution time. Spraying the TLC plate with Dragendorff reagent obtained orange coloured spot observed corresponding to sibutramine HCl.

The method showed a good specificity. There was not observed any interference from the sample components and others at $\mathrm{Rf}$ of sibutramine $\mathrm{HCl}$ (Figure 2). The linear regression analysis of the calibration curve between the amount of sibutramine $\mathrm{HCl}$ and peak area showed good linear relationship over the concentration range of $0.5-5 \mu \mathrm{g} / \mathrm{spot}\left(\mathrm{r}^{2} \geq\right.$ 0.9986 ) (Figure 3 ). The LOD and LOQ values obtained were at $217.5 \mathrm{ng}$ and $724.9 \mathrm{ng} / \mathrm{spot}$, respectively.

The precisions of the method were found to be satisfactory as the RSD values determined by repeatability and intermediate precision studies were all less than $2.0 \%$ as shown in table I. The accuracy of the method was determined from the recovery studies. 
Hayun

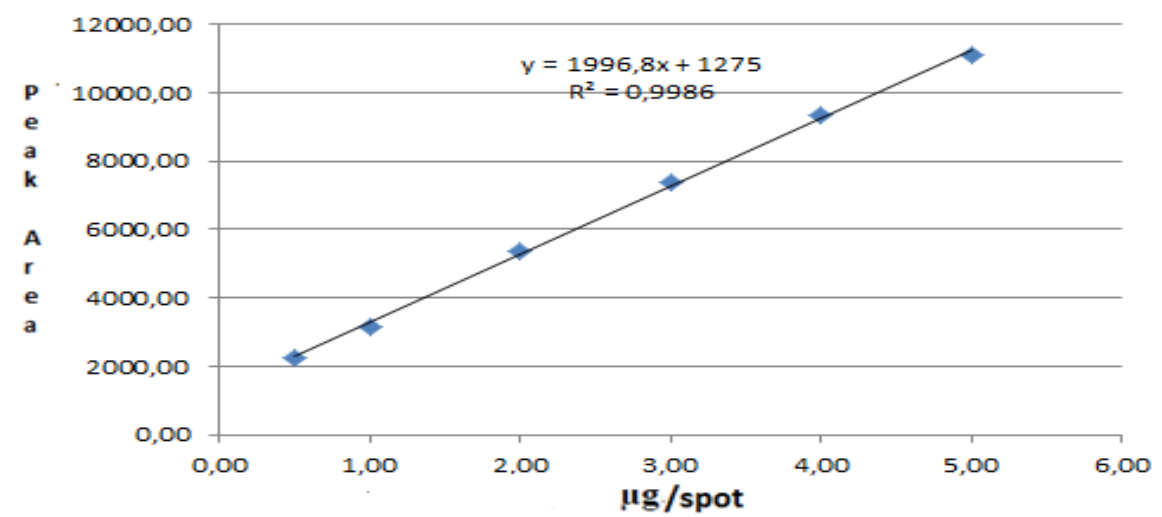

Figure 3. Calibration curve between peak area and concentration.

Figure 4. UV spectrum of the chromatogram spot (A) and TLC chromatogram after spraying with Dragendorff reagent.
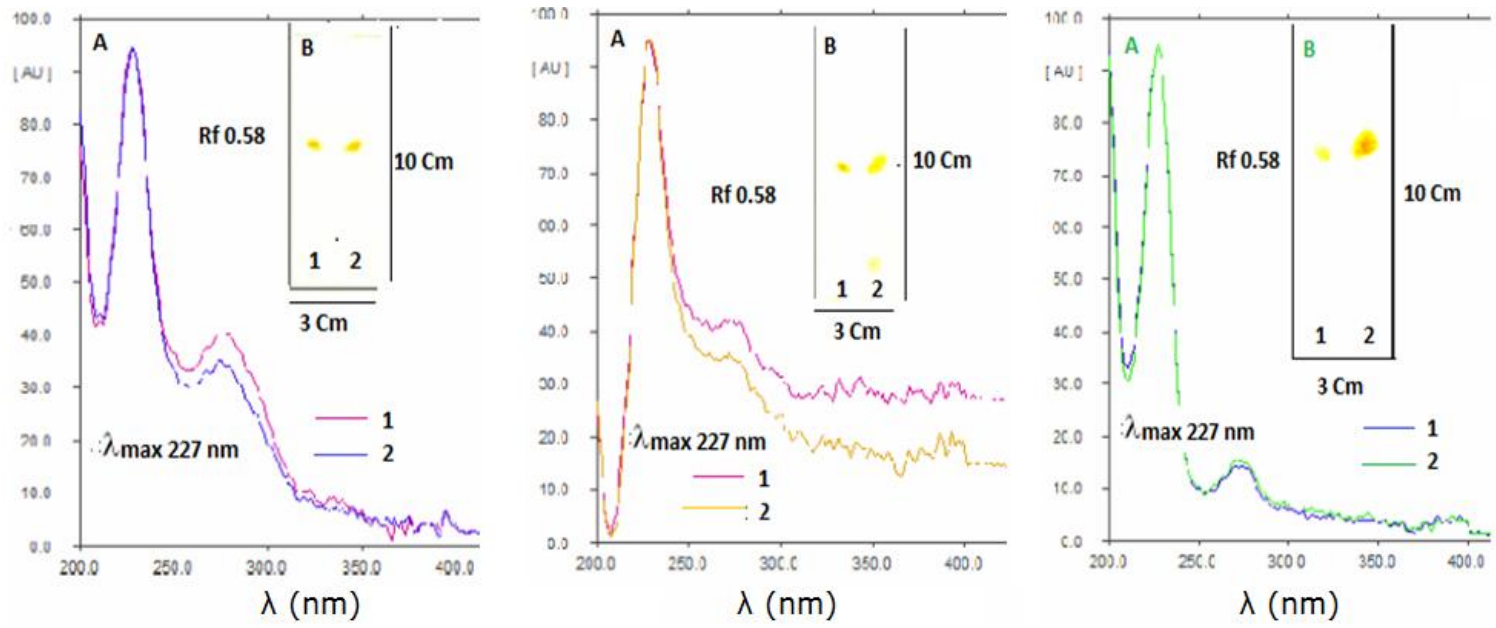

Sampel AR

Sampel SU

Sampel DI

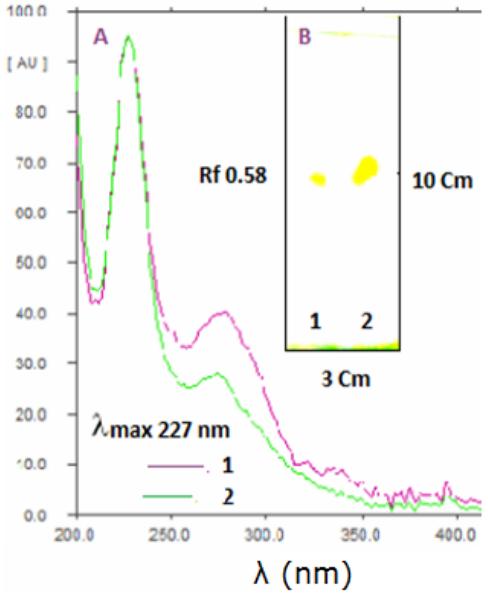

Sampel SL

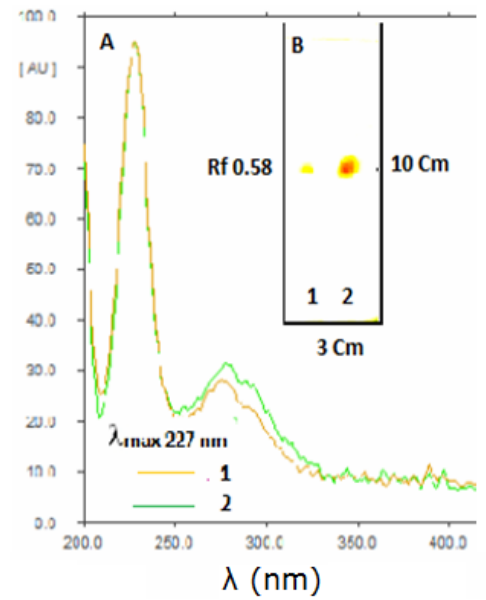

Sampel LK

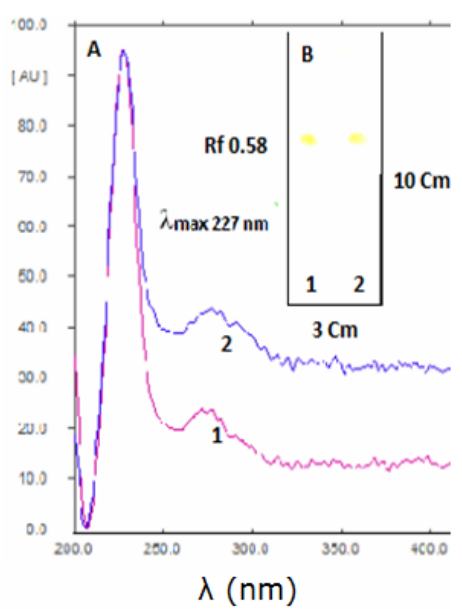

Sampel LM 
Mean recoveries obtained from blank sample addition to give 1,2 and $3 \mu \mathrm{g} /$ spot sibutramine $\mathrm{HCl}$ were $99.57 \pm 1.57 \% ; 100.32 \pm 2.06 \%$, and $99.20 \pm 1.24 \%$, repectively (Table II).

Qualitative analysis of seven samples found six samples containing sibutramine (Figure 4). Spots from the six samples had similarity in Rf, UV spectrum and colour with those from a sibutramine $\mathrm{HCl}$ standard. Results of the determination of sibutramine $\mathrm{HCl}$ concentration in the samples showed that the slimming products contain $2.45-26.24 \mathrm{mg}$ sibutramine $\mathrm{HCl}$ per single dosage of slimming products (Table III). The size and colour intensity of the spots were in line with the amount of sibutramine $\mathrm{HCl}$ (Figure 4B, Table III). The results illustrated the alarming public health situation, particularly since sibutramine increases the risk of cardiovascular events.

\section{CONCLUSIONS}

The above proposed TLC-densitometric method for the determination of sibutramine adulterated in herbal slimming product was successfully developed. The method gave satisfactory specificity, linearity, precision and accuracy validation criteria, was simpler and lower operating cost, could therefore be useful to small laboratory or local health authorities to conduct safety surveillance of herbal slimming products.

\section{ACKNOWLEDGEMENTS}

The author are thankful to Faculty of Pharmacy, Universitas Indonesia, Depok, West Java, Indonesia, for providing research facility.

\section{REFE RE NCES}

Adamovics JA. and Eschbach JC., 1997, Planar Chromatography, in Chromatographic Analysis of Pharmacenticals, (Edited by Adamovics, JA), Marcel Dekker, New York., p. 57-77.

Ariburnu E., Uludag M.F., Yalcinkaya H. and Yesilada E., 2012. Comparative determination of sibutramine as an adulterant in natural slimming products by HPLC and HPTLC densitometry. $J$. Pharm. and Biomed. Anal., 64- 65: 77- 81

Ancuceanu R., Dinu M. and Arama C., 2013. Weight loss food supplements: Adulteration and multiple quality issues in two products of Chinese origin. Farmacia, vol. 61, 1, 28-44

Badan Pengaw as Obat dan Makanan (BPOM)

RI, 2014. Hasil Pengawasan Obat

Tradisional Mengandung Bahan Kimia

Obat.

http:/ /www.pom.go.id/new/index.php/ view/pers/242/Hasil-Pengaw asan--

Obat-Tradisional-Mengandung-Bahan-

Kimia-Obat.html

Bogusz MJ., Hassan H., Enazi E., Ibrahim Z., Tufail M. and Bohrer D., 2006. Application of LC-ESIMS-MS for detection of synthetic adulterants in herbal remedies. J. Pharm. Biomed. Anal. 41. 554-564.

Canadian Medical Association, 2002. Obesity Drug Sibutramine (Meridia): Hypertension and Cardiac Arrhythmias. Can. Adverse Reaction Newsletter, 1307-1308.

Carvalho LM., Martini M., Moreira APL., de Lima APLS., Correia D., Falca T., Garcia SC., de Bairros AV., do Nascimento PC. and Bohrer D., 2011, Presence of synthetic pharmaceuticals as adulterants in slimming phytotherapeutic formulations and their analytical determination. For. Sci. In., 204, 6-12

Chen SP., Tang MH., Ng SW., Poon WT., Chan AY. and Mak TW., 2010. Psychosis associated with usage of herbal slimming products adulterated with sibutramine: a case series. Clin. Toxicol., 48(8): 832-8.

Daglioglu N and Akcan R., 2012. Sibutramine, chinese herbal drug, clinical medicine, forensic toxicology . Nobel Med, 8(1): $100-102$

Departemen Kesehatan Republik Indonesia, 1994. Kodifikasi Peraturan Perundangundangan Obat Tradisional. Direktorat Jendral Pengawasan Obat dan Makanan: Departemen Kesehatan Republik Indonesia.

Haneef J., Shaharyar M., Husain A., Rashid M., Mishra R., Siddiqueb N.A. and Pal M., 2013. Analytical methods for the detection of undeclared synthetic drugs in traditional herbal medicines as adulterants. Drug Test. Analysis, 5, 607613

Health Authority Abu Dhabi (HAAD), 2012. Adulterated Herbal Weight Reduction 
http://www.haad.ae/haad/tabid/58/ctl /Details/Mid/417/ItemID/262/Default .aspx

ICH guidelines, 2005. International Conference on Harmonisation Guidelines on Validation of Analytical Procedure: Text and Methodology Q2 (R1), Geneva, 1-8.

Kanan S., Abu-Yousef LA., Gunasekar C., Abdo N. and Narasimhan S., 2009. Detection and quantification of synthetic drugs in herbal slimming formula. Eur. J. Sci. Res. 34. 348-357.

Khazan M., Hedayati M., Kobarfard F., Askari S. and Azizi F., 2014. Identification and Determination of Synthetic Pharmaceuticals as Adulterants in Eight Common Herbal Weight Loss Supplements . Iran Red Crescent Med J., 16(3): 15344.

Mathon C., Ankli A., Reich E., Bieri S. and Christen P., 2014. Screening and determination of sibutramine in adulterated herbal slimming supplements by hptlc-uv densitometry. Food Addit Contam. Part A. Chem Anal Control Expo Risk, Assess., 31(1):15-20.

Monika H., Munish G., Jyoti S., Sandeep S. and Sneha D., 2011. A Recent Update on Undeclared Chemicals in Herbal Formulations, JPBMS, 9 (03), 1-4.

Oberholzer HM., Bester MJ., van der Schoor C. and Venter C., 2014. Weight Loss Products Adulterated with Sibutramine: A Focused Review of Associated Risks. J. Endocrinol Diabetes Obes., 2(4): $1061-7$

Phattanawasin P., Uthai S., Tasamaporn S., Jariya A. and Sarunyaporn K., 2012. Quantitative Determination of Sibutramine in Adulterated Herbal Slimming Formulations by TLC-Image Analysis Method. For. Sci. In., 219, 96100.

World Health Organization (WHO), 2005. National policy on traditional medicine and regulation of herbal medicines. Report of a WHO Global Survey, Geneva. 